\title{
Legal regulation of international adoption in Lithuania and Portugal
}

\author{
Perkumienė Dalia, ${ }^{1}$ Beriozovas Olegas, ${ }^{2}$ Escudeiro Maria João ${ }^{3}$ \\ ${ }^{1}$ Vytautas Magnus University Agriculture Academy, Kaunas, Lithuania \\ ${ }^{2}$ Kazimieras Simonavičius University, Vilnius, Lithuania \\ ${ }^{3}$ Polytechnic Institute of Lisbon and of ISCPSI, and PhD in Criminal Legal Sciences, Portuguese \\ Catholic University, Lisbon, Portugal
}

\begin{abstract}
ANNOTATION
One of the most important rights of the child is the right to grow up in a family. This is guaranteed by the State which takes measures to implement it. In both national and cross-border adoptions, the right of the child to be adopted and the opportunity to grow up in a new family must be guaranteed. Adoption conditions are created for both citizens of the Republic of Lithuania and citizens of foreign countries, but the conditions differ substantially. The entry into force of the law in 2012 has had a significant impact on the adoption of foreign nationals by restrictions on international adoption. Difficulties in the adoption process are manifested through the ineffectiveness of laws. The permission for only married foreign couples to adopt only children with special needs, the lack of real access to a potential child before consenting to adoption, only illustrates why the number of children willing to be adopted in Lithuania. The problem of adoption and international adoption in Portugal presents a scope that needs to be limited. Portugal was not unaware of the need to deepen the effectiveness of the rights of the child in its legal regime, which is also influenced and linked to the various international instruments to which Portugal was a signatory.
\end{abstract}

Key words: child, adoption, child's right to grow up in a family, international adoption.

\section{INTRODUCTION}

Research problem and degree of the research. Protecting the rights of the child is one of the most important issues today, both nationally and internationally. The situation is particularly complicated when it comes to international adoption. The practice of adoption transcends all cultures and has long since existed, having played different functions over time. This practice has come to reflect social changes relating to how society faces a child's needs, the way of exercising parental responsibilities and the needs of birth parents and adoptive parents. This is a subject increasingly relevant within the phenomenon of globalization and the urgency given to children and their rights in contemporary society. This is a subject for today and for the future.

The adoptive child, due to his or her subjective characteristics, is unable to exercise his or her rights properly. This obligation must be exercised by the child's parents or the State and its authorities. Although the Constitution of the Republic of Lithuania guarantees that every child has the right to grow up in a family, many children do not have a family and are forced to grow up in foster care. Adoption is a rather complex and lengthy process, especially when it comes to cross-border adoption. Adoption aims at finding a family and a home for the child. In the case of cross-border adoption, the State has a duty to ensure the protection of the rights and legitimate interests of the child. Adoption, both nationally and internationally, has the same goal of ensuring the best interests and well-being of the child. The role of the court, which assesses whether the child will be able to grow safely and develop fully in the new family, is crucial in the adoption process. In this situation, it is necessary to identify and evaluate all the circumstances related to the child's upbringing, quality of life and education. 
Adoption is a process that entails certain stages, but like most other areas, it does not escape difficulties. In Lithuania, the number of families at social risk, and of children living in institutions, is still quite high.

In Portugal, the strong connection between the principle of the child's best interests, a major principle of family law, deeply influences the entire legal establishment, especially in the matter of international adoption. The placing of children in a foreign family is a subsidiary option, in great part due to the difficulties that they will find from the moment they exit their country of origin. Difficulties such as differences in culture, language, religion, habits, among others that may result in children's cultural uprooting and affect their cultural identity, beyond the break with their biological family, are implicit in any adoption.

We shall analyze the general aspects of adoption, international and national sources of law, especially the 1993 Hague Convention on Protection of Children and Cooperation in respect of Intercountry Adoption (enacted 1995, hereinafter The Hague Adoption Convention), in which the Member States, by means of bi-lateral or multi-lateral agreements, sought to regulate this kind of adoption, and the unifying Portuguese Law n 143/2015, of 8 September 2015.

Subject of the article: protection of the rights of the child and problems in cross-border adoption.

Aim of the work: to analyze whether the rights of the child in the case of international adoption are violated.

Research methods: teleological, historical, comparative analysis of legislation, generalization, analysis, and synthesis of scientific literature, descriptive, comparative, analytical methods.

\section{RESEARCH RESULTS AND DISCUSSION}

\section{The concept of the child and his/her right to grow up in a family}

Article 2 of the 1959 United Nations Declaration on the Rights of the Child emphasizes that a child is a person under the age of 18 unless otherwise provided by law. The UN Declaration on the Rights of the Child states that any person under 18 years of age shall be deemed to be a child unless the applicable law has previously recognized him or her. National legislation uses not only the term "child" but also the terms "minor" (Commentary of the Ombudsman of the Republic of Lithuania, 2004-2008) and "underage" (Proceedings of the Senate of the Supreme Court of Lithuania, 2004). The Civil Code of the Republic of Lithuania provides for two categories of minors: those who have no legal capacity for civil status and those who have partial legal capacity, who are 14 years of age and who enter into transactions with the consent of their parents or guardians (Civil Code of the Republic of Lithuania, 2001, art. 2.8). A person over the age of 14 has the right to dispose of his or her income and assets independently. A person of 18 years of age can become fully civil, but not a person under 18 . Article 13 (1) of the Criminal Code of the Republic of Lithuania (CC) states that a person who has reached the age of sixteen years before committing a crime or a misdemeanor is liable under this Code (Criminal Code of the Republic of Lithuania, 2000). According to the Lithuanian CC, a person of sixteen years of age, although a minor, is already mentally advanced and can understand the nature and substance of his or her actions: what you can and cannot do and be responsible for your actions (Piesliakas, 2009). 
It should be noted that the United Nations Convention on the Rights of the Child is the main instrument governing the rights of the child. Protecting the rights of the child is an integral part of the whole human rights system. The first relevant document is the Declaration on the Rights of the Child adopted in 1959. In 1989, the United Nations General Assembly adopted the Convention on the Rights of the Child. In 1990, for the first time, the New York Summit included the issue of children as one of the key political issues. Since then, the issue of the child has been the subject of a broader investigation to ensure the rights of the child. Lithuania on 5 January 1995, it acceded to the United Nations Convention on the Rights of the Child, which it ratified on 3 July 1995, thereby committing itself to taking all necessary legal, administrative and other measures to implement, respect and guarantee the rights of the child. As a result of Lithuania's efforts to strengthen the protection of children's rights, the Law on Fundamental Rights for the Protection of the Rights of the Child (March 14, 1996, adopted in June 1996), guaranteed the fundamental rights and duties of the child.

One of the fundamental rights of the child is the right to maintain family ties. In the event of adoption, the child loses contact with his or her family (Sagatys, 2006), which means that adoptive parents become his or her new parents. Article 3.227, first paragraph of Book 3 of the Civil Code (2001), states that adoption removes the personal and property rights and duties of parents and children and their relatives by origin and establishes the personal and property rights of parents and their relatives and adopted children and their descendants as relatives by origin, which means that the new family of the child is the primary one in which the child has the right to grow up. However, the child is given the right to know who his or her biological parents are and to know their origin. Cases of children below the age of majority who seek to know their origin, but do not object or do not obtain the consent of their new parents, are not admissible before the Lithuanian courts. In this case, the CC provides that "without the consent of the adoptive parents, no details of adoption may be disclosed until the child reaches the age of majority." This is done to preserve the formation of a new family and to best protect the interests of the adopted child.

The child also has the right to know his or her origin. This right is provided for in Article 3.137 (2) of the CC. The origin of a child is based on the rights and duties of the child and parents, which means that the child's parents are his or her biological parents with whom he or she is related by blood. Adoption is the process of adopting a child by others who have no kinship or blood relationship with the adoptive child, so it is the adoption process that is the key to the child's right to know his or her origin. A person can take possession of his or her origin documents at the age of majority. The right to know one's origin stems from the human right to respect for one's private life, enshrined in Article 8 of the ECHR. However, there is no specific law that imposes an obligation on new parents to provide information on the child's origin. In general, this decision should be made by the parents in the best interests of the child. Disclosure of the origin of a child may not always be beneficial to the child, and its potential consequences need to be properly assessed before it is disclosed.

The right of the child to grow up in a family is one of the fundamental rights of the child enshrined in basic international law. The United Nations Declaration on the Rights of the Child states that a child can develop fully and harmoniously, and needs love and understanding. He or she must, if possible, grow up with a sense of parental care and responsibility (United Nations Declaration on the Rights of the Child, 
1959). The European Convention on Human Rights and Fundamental Freedoms states that "everyone has the right to respect for his or her private and family life, his or her home and his or her confidentiality" (European Convention on Human Rights and Fundamental Freedoms, 1995). The International Covenant on Civil and Political Rights states that "the family is the natural and fundamental cell of society and is entitled to protection by society and the State" (International Covenant on Civil and Political Rights, 2002). The right of the child to grow up in a family is also protected by national law. Article 38 of the Constitution of the Republic of Lithuania states that "the family is the basis of society and the state, and the state also protects the family, motherhood, fatherhood and childhood" (Constitution of the Republic of Lithuania, 1992). Article 9 (1) of the Law on Fundamentals of the Protection of the Rights of the Child states that a child shall have the right from birth to a name, surname, nationality, and citizenship, to family and other relationships, foster homes for children, help with adoption, and be provided opportunities to find new guardians who can give the child a chance to grow up in a family.

Article 9 of the United Nations Convention on the Rights of the Child (1995) provides that "States Parties shall ensure that no child is separated from his or her parents against their will, unless the competent authorities, in accordance with a judicial decision and applicable law, determine in due course that such separation is necessary in the best interests of the child". This presupposes that the child has a right to contact with both parents, and that the obligation to enforce this right rests with the State, which has the obligation to provide information relating to the place of residence of the children or parents if they have been separated by State intervention.

Article 18 of the United Nations Convention on the Rights of the Child (1995) states that "Parents or, as the case may be, legal guardians, have the primary responsibility for the upbringing and development of the child. The best interests of the child will be their basic concern" (Convention on the Rights of the Child, 1995). Article 4 (7) of the Law on Protection of the Rights and Fundamental Rights of the Child states that the rights of the child must first and foremost be guaranteed by parents and other legal representatives of the child. Article 3.163 (1) of the Civil Code states that the enforcement of the rights of minor children is the responsibility of the parents (Civil Code of the Republic of Lithuania, Article 3.163, 2001). All this legislation speaks to parents and their important role in the child's life. Parents have the right and the duty to bring up children, to care for them, to maintain them, and to create favorable conditions for their development. This implies that the right of the child to grow up in the family is important not only because it is best for the child to develop, but also because parents are the best guarantor of the child's rights and their realization, and every effort should be made the ability to grow in a family environment.

The problem of adoption and international adoption in Portugal presents a scope that needs to be limited. Portugal was not unaware of the need to deepen the effectiveness of the rights of the child in its legal regime, which is also influenced by and linked to the various international instruments to which Portugal was a signatory. Examples of these are: the Convention on the Rights of the Child, signed in New York in 1989 and ratified through the Assembly of the Republic Resolution No. 20/90; the United Nations Standard Minimum Rules for the Administration of Juvenile Justice ("The Beijing Rules") resulting from the seventh United Nations Congress for the Prevention of Crime and Treatment of Offenders, approved by General Assembly resolution 40/33, of 1985; “The Tokyo Rules” which concern 
the minimum rules for approval of non-custodial measures, resolution of AG 45/110 of 14 December 1990; and the United Nations guidelines for the Prevention of Juvenile Delinquency, called "The Riyadh Guidelines" (approved by resolution 45/112 of 1990), among others.

The Portuguese Constitutional Law provides in Article 36 (Family, marriage and affiliation)

"1. Everyone has the right to find a family and to marry on equal terms.

2. The law regulates the requirements and effects of marriage and its dissolution, by death or divorce, regardless of the form of celebration.

3. Spouses have equal rights and duties regarding civil and political capacity and the maintenance and education of children.

4. Children born out of wedlock cannot therefore be discriminated against and the law or official offices cannot use discriminatory designations relating to affiliation.

5. Parents have the right and the duty to educate and maintain their children.

6. Children cannot be separated from their parents, except when they do not fulfill their fundamental duties towards them and always by judicial decision.

7. Adoption is regulated and protected under the terms of the law, which must establish swift forms for the respective processing."

Also, article 69 of the Portuguese Constitution, imposes on society and the State the duty to protect children "with a view to their integral development, especially against all forms of abandonment, discrimination and oppression and against the abusive exercise of authority in the family and in other institutions".

In conclusion, the right of the child to grow up in a family is one of the most important rights of the child. It is guaranteed by the State which takes the measures to implement it. In both national and cross-border adoptions, the right of the child to be adopted and the opportunity to grow up in a new family must be guaranteed. It cannot be said categorically that finding a family alone will provide the child with the right conditions for growing up in the family, but other conditions such as arrival, education, health and life must also be considered.

\section{LEGAL REGULATION OF THE ADOPTION PROCESS}

The legal regulation of adoption in Lithuania is implemented in the norms of the Civil Code of the Republic of Lithuania. In addition to the national laws governing adoption procedures, the Institute for the Regulation of Adoption Laws is composed of the United Nations Convention on the Rights of the Child and the 1993 Specialized Convention. The norms of the Hague Adoption Convention, which are directly applicable in connection with the examination of applications of foreign nationals for the adoption of children who are Lithuanian citizens.

First of all, it should be noted that the adoption relationship is governed by the law of the state of the child's habitual residence (Civil Code of the Republic of Lithuania, Article 1.33, 2001). However, citizens of another state who wish to adopt a child domiciled in the Republic of Lithuania in contravention of the law of the habitual residence of the adoptive parents may rely on the adoption laws of the habitual residence of the adoptive parents as long as they do not harm the child. It should be noted that adoption in 
Lithuania is allowed, but not all other countries allow adoption (Civil Code of the Republic of Lithuania, Article 1.33, 2001).

According to Sharee'ah (Islamic Law), there is no legal adoption. It is forbidden for a person to legally adopt a son or daughter whose biological father is still alive. But the opposite is true with orphaned children. Islamic law does not prohibit a man from bringing home the orphan he wants to raise, feed, teach and otherwise treat him like his true child. The same is true with stepchildren, who are considered the same as orphans (Adoptions in Islam, 2019).

The other country mentioned is the United States of America (USA). Although the US is one of the most adoptive countries in the world, over time it has been banned from adopting from certain countries. One such is Russia, which has completely banned US citizens from adopting children from Russia, while other countries like China have imposed very strict rules that eliminate most adoptive families. Vietnam, Ethiopia and Guatemala have also banned the adoption of US citizens to some extent, due to the prevalence of corruption in the US and the fact that in some cases families are being deceived or forced to surrender their children (Care2, "Why Foreign Countries are Banning American Adoption", 2019).

As mentioned above, the main purpose of adoption is to ensure the well-being of the child. The Hague Adoption Convention identifies the basic measures that must be taken to protect the best interests of the child. First and foremost is ensuring that a child can be adopted. Adoption is only permitted for children who are on the register of adopted children, except in the case of the adoption of a child of a spouse or the adoption of a child living in the family of the adopter (Article 3.209 CC). The main institution dealing with issues related to adoption procedures is the State Child Rights Protection and Adoption Service, which organizes adoption in the Republic of Lithuania for citizens of the Republic of Lithuania and foreigners (Approval of the Regulations of the State Child Rights Protection and Adoption Service under the Ministry of Social Security and Labor, 2005).

Article 3.209 CC of the Republic of Lithuania Point 3 stipulates that child of at least 3 months of age may be adopted. Such determination of the child's age enables the woman who has given birth to not lose her rights if she leaves the child in the maternity hospital due to certain psychological, material, or other problems. CC 3.029 Art. Paragraph 4 states that adoption of their children, sisters and brothers is not allowed. Such prohibition is consistent with the existing system of family legal relationships, as the legal relationship between the child and his or her biological parents is regulated by the institutions of recognition or establishment of paternity (Article $3.137 \mathrm{CC}$ ). An adoptive child may only be adopted by the spouse of the adoptive parent. (Art. 3.209, p. 5) The aim here is not only to strengthen the family but also to ensure the safety of the child within the family. If the child is adopted by one person (if one of the adoptive parents is deceased or has been permanently restricted by authority), only the spouse or spouse of the existing adopter is permitted to adopt.

CC 3.029 Art. 6 p.m. maintains that adoption by siblings is permitted only in exceptional cases where the health of the sisters and the siblings cannot be guaranteed or where, for various reasons, the siblings have already been separated and there is no possibility of securing their cohabitation. In this case, the aim is to ensure the closest possible connection between the children of the adoptive parents who are linked by a "side" kinship. This provision leaves the possibility of adopting sisters and siblings 
together without separating them. Exceptionally, when sisters and brothers cannot be adopted together, this is one of their health problems. e.g., when one of the children requires complex surgery or special care that can only be provided by specific adopters. Or if the adoptive parents are unable to raise and properly raise other adoptive sisters or brothers.

According to Article 3.212 of the Civil Code, the written consent of the child's parents, approved by the court, is required for adoption. This is necessary because, without the consent of the parents, the child cannot be placed on the list of adoptees or adopted at all. It is only with the parents' agreement that they cannot raise a child, take care of him or her, and that it is best for him or her to find a new family who can take care of him or her properly. The exception provided for in Article 3.212 (3) of the CC is that consent may be given to an adopter if he or she is a relative. The same child can only be offered to the same family once.

Paragraph 2 of Article 3.212 of the CC states that if the parents of an adopted child are minors or incapacitated, the written consent of their parents or guardians (guardians) approved by the court is required. Parents of minors are persons under the age of 18 who have no legal capacity to perform the duties of the child, so the law provides that in such a case the consent of the above-mentioned persons must be given for their adoption.

Priority to adopt is given to relatives, spouses adopting several children without siblings, citizens of the Republic of Lithuania adopting the child or adopted children of the spouse, and persons seeking adoption, whom they maintain and bring up at home.

It should be noted that persons wishing to adopt must be included in the official list which is being prepared by the Adoption Service under the Ministry of Social Security and Labor. Foreigners wishing to adopt a citizen of the Republic of Lithuania were, until 1 January 2012, included in a separate list of permanent residents and foreigners of the Republic of Lithuania. After 2012, that changed.

Citizens of the Republic of Lithuania and foreigners permanently residing abroad are offered to adopt a citizen of the Republic of Lithuania, if 6 months after the child was included in the list of possible adopted children, there were no persons residing in Lithuania who would like to adopt the child to their family.

In summary, it is possible to state that the conditions of adoption from Lithuania are created both for the citizens of the Republic of Lithuania and the citizens of foreign countries, but the conditions differ substantially. The entry into force of the law in 2012 has had a significant impact on the adoption of foreign nationals by the restrictions on international adoption.

Is important also to analyze the Portuguese legislation in respect of this matter. The Portuguese law presents a notion of adoption in art. $1586 .^{\circ}$ of the Civil Code (CC-PT), as a "bond that, like natural affiliation, but regardless of blood ties, it is legally established between two people." In this we can't help following Pires de Lima and Antunes Varela who affirm that "(...) adoption is based on an individual, sentimental and different from procreation, but as real as this biological bond" (Fernandes Pires de Lima and Antunes Varela, Código civil anotado, 1995).

Adoption is a personal act and should only be used when the maintenance resources for children or adolescents in the natural family. The child's best interest is the objective to be taken with the adoption, as stated in the requirements of adoption rules in art. 1974 of the CC-PT. 
According to the Portuguese legislation it should be noted that the age of majority is, in effect, in accordance with article 130. CC-PT sets it at 18 years old.

Adoption makes the adopter's biological children and adoptees equal, and the adoption must not involve unfair sacrifices for the other children of the adopter. Adoption must be declared by judicial sentence, being therefore a legal relationship, having as biological affiliation paradigm. However, this is not simply a fiction, rather, it precedes an affective fact, a psychological, affective and social reality that deserves the protection of the law, as long as it does not violate the best interests of the children.

Considering the current adoption regime in Portugal, there are no longer adoption modalities as to the effects since adoption is now a single regime as to its effects. But as for the number of adopters, we can still distinguish between a single (one person) and a joint (two people) adoption. We can distinguish between national adoption and international adoption, taking into account that present specific legal regimes are not exactly equal, and that international law on adoption implies changing the child's country of habitual residence.

Adoption in Portugal is only declared by court order. The first step of international adoption is for the resident in Portugal to present his/her intention to adopt a child residing abroad to the social security organization in his/her residence. The rules for applying for national adoption apply at this office, with the necessary adaptations. The social security body is responsible for conducting the investigation of the application for international adoption, in accordance with information made available regarding requirements and evidence required by the country of origin. Subsequently, the application must be submitted to the Central International Adoption Authority which verifies the application and forwards it to the competent authority of the country of source. Regarding adoption decisions, international law is covered by bilateral legal agreements that do not require that foreign judgments are also automatic. In cases that do not fit in these two cases, the effectiveness of the foreign adoption decision in Portugal depends upon a recognition by the Central International Adoption Authority. A decision should not be recognized if it is manifestly incompatible with the principles of international public order of the Portuguese State. So, it is only possible to adopt a child from a country that accepts the application transmitted by the Central International Adoption Authority, and if it is also an institute known on the legal system of origin of the minor, regardless of whether it is a country linked to the the Hague Adoption Convention.

The effects of international adoption that do not normally occur in national adoptions will be those related to the adopted nationality. Since the acquisition of nationality is a matter of public law, it will be up to each state to regulate this matter. International adoption may therefore result in the loss or maintenance of the child's nationality and whether the adopter's nationality is obtained.

In the case of the adoption by Portuguese residents of children residing in a foreign country, according to art. 5 of the nationality law, Law no. 37/81, of 3 October, republished by Organic Law No. 9/2015, of 29 July: "The one fully adopted by a Portuguese national acquires Portuguese nationality." This article only applies, as it is clear from the law, if the resident in Portugal also has Portuguese nationality. If the resident in Portugal does not have Portuguese nationality, the adopted child may always acquire Portuguese nationality in another way enshrined in the law. 


\section{DIFFICULTIES IN LEGAL REGULATION AND IMPLEMENTATION IN THE INTERNATIONAL ADOPTION PROCESS}

In Lithuania, analyzing statistics from 2013, it can be stated that foreign citizens adopted 80 children; in 2014, 78 children; 2015, 62; 2016, 67; 2017, 47; 2018, 52; and 2019, 29 adopted children. Considering the number of possible adoptions, which reached 372 in 2019 (http://www.vaikoteises.lt/ ivaikinimas-ir-globa/statistika, 2019), it can be stated that the number of children adopted abroad remains quite high, it should be noted that the number of adopted children in Lithuania is decreasing every year. The goal of state policy is to reduce the number of children in foster care, which is a positive development. However, less attention is paid to the effective implementation of the adoption policy of the Republic of Lithuania (Gončiarova; Tamutienè, 2016.). This suggests that there is no effective means to achieve this, which prevents the stated objectives from being achieved.

Regarding the problems related to the adoption of foreign nationals, the issue of the removal of the list of foreign nationals wishing to adopt in Lithuania is being discussed. The main legal act which restricts the possibilities of foreigners to adopt in the Republic of Lithuania is the Law "On the Minister of Social Security and Labor of the Republic of Lithuania June 3 no. A1 - 162 on Approval of the Description of the Procedure for Granting the Authorization to Act in the Republic of Lithuania to Exercise International Adoption (Amendments to the Description of the Procedure for the Granting of Foreign Authorities..., 2012)". Following the enactment of this law, changes were introduced so that from April 1, 2012, foreigners permanently residing abroad may apply to the State Child Rights Protection and Adoption Service only for the adoption of children with special needs. In addition, only married foreign couples will have the right to adopt in Lithuania (Amendments to the Description of the Procedure for the Granting of Foreign Authorities..., 2012). According to Odeta Tarvydiene, "foreigners wishing to adopt a healthy child under the age of 5-6 years had to wait for 5-7 years or even longer (Tarvydienè, 2019). In this case, there may be long queues of foreigners willing to wait to adopt. Under these conditions of adoption, foreigners are more likely to adopt children with special needs. Adoption of children with special needs takes less time, which means that children with serious health problems, older (8-12 years), three or more siblings can be adopted within 0.5-2 years (Tarvydienè, 2019). This is also reflected in the statistics, according to which the adoption of foreigners from Lithuania has fallen quite significantly.

Another important reason is that the possibility to adopt a child in Lithuania is left only to spouses. In this way, the right to allow single persons to adopt a child from Lithuania is restricted, even though they may meet the requirements for adopters. Because of the importance of the environment for the child's development, it is important for the child to grow up in a family, feeling the love and care of the parents, whether adopted by one or both parents. The preamble to the Hague Adoption Convention states that the harmonious development of a child's personality is a prerequisite - to grow up in a family environment, in an atmosphere of happiness, love and mutual understanding.

One of the drawbacks is the lack of access to the child before consenting to the adoption. In order for prospective adoptive parents to have access to the child, the adoption service will decide that international adoption is in the best interests of the child (On Approval of the Description of the Procedure of Adoption Accounting in the Republic of Lithuania, 2002). It shall then inform the citizens of the Republic of Lithuania who are habitually resident or resident or the central authorities or their 
accredited bodies representing them of the possibility of adoption and provide information relating to the potential child to be adopted. They must reply to the Adoption Service, either directly or through their representative central authority or its accredited authority, no later than 30 calendar days after they have received information on the prospective adoptive child (On Approval of the Description of the Procedure of Adoption Accounting in the Republic of Lithuania, 2002). The adoption service then gives permission to see the child. This means that it is only with the consent to adopt that the prospective adoptive parents can become acquainted with the adopted child. Although new adoptive parents and new homes are found for the child, this does not mean that there is a connection between them. Article 3.222 of the Civil Code stipulates that, at the request of the state adoption authority or on its own initiative, the court may set a probationary period of six to twelve months before adoption and transfer the child to live, educate and maintain the future adoptive family. A probationary period is granted if it is believed that the child did not have enough communication time with the adoptive parents and no connection could be established between them. In this case, the child is given the opportunity to stay in a new environment, the opportunity to establish a family relationship with future adoptive parents, depending on age, and to decide whether such adoption will be beneficial to him or her. However, if the child does not fit in the new environment during the probationary period, he or she is returned to the care home. This can also lead to certain negative consequences for the child, he/she may feel vulnerable, unloved, and may avoid agreeing to be adopted in the future. In summary, it can be stated that only with the consent of adoptive parents can get acquainted with the child and do not have a real opportunity to communicate and establish relations before the adoption, which may influence the decision of the families willing to adopt from Lithuania.

In conclusion, the international adoption process in Lithuania has some shortcomings: the large number of families at social risk, according to the Order on Child Welfare 2013-2018 the ineffectiveness of the program approval; the removal of the list of aliens seeking adoption in Lithuania; the possibility of adoption for spouses only; and the lack of access to the adopted child before consenting to the adoption. These are some of the reasons why an effective and smooth adoption process cannot be achieved.

Regarding Portuguese difficulties in implementing international adoption, there is a specific legal regime requiring a change of the child's country of habitual residence. The elements that lead to classifying adoption as a complex act do not seem to have very relevant specificities in the matter of international adoption, so we can consider that it has the same legal nature as the general institute. Nothing prevents bilateral judicial agreements between and with non-contracting countries of the Hague Adoption Convention, to regulate the process of international adoptions between and with these countries. Portugal can enter into bilateral legal agreements with interparty effects, agreeing to adoptions outside the context of the Hague Adoption Convention. International adoption shares with national adoption a large part of its effects. However, due to the nature of international situations, there are some effects that may be generated and that are not paralleled in national adoption, namely those related to the adopted nationality. Since the acquisition of nationality is a matter of public law, it will be up to each state to regulate this matter.

The adoption process requires a system of great interdisciplinary and interinstitutional collaboration, coordinated and dialoguing, between social security bodies, courts, private or official institutions that 
are in charge of children at risk, and also among all citizens, families and any bodies that are aware of children without a normal family environment.

So, the major difficulty of the adoption process in Portugal is its duration, as it takes an average of 2 to 5 years to conclude the process.

\section{CONCLUSIONS AND PERSPECTIVES}

1. The right of the child to grow up in a family is enshrined in the basic international instruments. It is within the family that the life and socialization of each child begins. It creates an atmosphere for the child to grow, develop and explore the world. The child should grow as much as possible to feel the love, care, and responsibility of his or her parents.

2. Adoption is a significant process in many states. The main international instrument governing adoption is the Hague Convention on Protection of Children and Cooperation in respect of Intercountry Adoption. States, in accordance with both their national and international legislation on adoption, seek to enable the child to grow up in a new family, while ensuring that such adoption best protects the rights and interests of the child.

3. The right of adoption shall be granted to citizens of the Republic of Lithuania and to foreign nationals, but the conditions of adoption shall be different for them. The provisions of the Civil Code grant Lithuanian citizens the right to adopt if they are of legal age, of up to fifty years of age, and of spouses. The new law allows foreigners permanently resident abroad to adopt only children with special needs.

4. In accordance with the practice of foreign states, it is determined whether the rights of the child have been violated in solving an adoption case. It is irrelevant whether adoption has taken place for the infringement to occur. However, in each case it is necessary to determine whether the best interests of the child have been considered. Any decision, irrespective of the best interests of the child, violates the best interests of the child in the event of adoption.

5. In accordance with the case law of the Lithuanian Courts, it is important, when determining whether a child's interests have been violated in the event of adoption, to properly apply the law and to take into account the interests of the child who can express his or her views.

6. Difficulties in the adoption process are manifested through the ineffectiveness of laws. The permission for only married foreign couples to adopt only children with special needs, the lack of real access to a potential child before consenting to adoption only illustrates why the number of children willing to be adopted in Lithuania.

7. In Portugal, the child's best interest is a fundamental concept in this matter, for a true concept of individual rights is one in which the child is considered a subject of rights, and not object of them. This is the guiding principle for the exercise of private responsibilities in relation to children, as well as public ones, and should be considered both in state and judicial decisions and actions. The child's best interest is an indeterminate legal concept, varying with the customs of each society, taking into evolutionary and dynamic nature, and depending on case-by-case evaluation.

8. International adoption in the Portuguese legal system is subordinate to the principle of subsidiarity, only being allowed when a placement is not feasible with a permanent family member for 
the child in their country of origin. This principle is due to the great risks that this type of adoption entails, being the greatest of all possible implicit problems with the child's travel to another country.

9. Another material principle at the international adoption institute is the primacy of deep psychological relationships. The decision that decrees the adoption can establish the maintenance of personal contacts between the adopted and members of the biological family. In the institute for international adoption this possibility is almost nil, due to the implicit displacement child's physical activity to another country.

10. In Portugal, after several years' discussion of the issue of adoption by same-sex couples, it was approved by Law No. 9/2010, of 31 May 2010, which allowed civil marriage between people from the same sex. But as for the ability to adopt, art. 3, 1 prohibited this, the possibility of adoption by spouses of the same sex being expressly excluded.

11. This continues to be a divisive issue in Portugal, and Law No. 2/2016, of 29 February, eliminates discrimination against persons of the same sex who live in a de facto union or are married, in access to adoption, civil sponsorship and other family legal relationships, making all the legal changes.

\section{REFERENCES}

1. Adoptions in Islam (2013). Accessed on 12 March 2020. Available online: http://www.islamweb.net/en/article/135420/adoption-in-islam.html.

2. Amendments to the Description of the Procedure for the Granting of Foreign Authorities to the Authorities of the Republic of Lithuania to Engage in International Adoption, (Official Gazette, 2012, No. A1-8).

3. Approval of the Description of the Procedure of Adoption Accounting in the Republic of Lithuania, (Official Gazette, 2002, No 1422), p. 52.

4. Approval of the Regulations of the State Child Rights Protection and Adoption Service under the Ministry of Social Security and Labor, (Official Gazette, 2005, No 1114), 5.2. p.

5. Care2, "Why Foreign Countries are Banning American Adoption". Accessed on 12 March 2020. Available online: http://www.care2.com/causes/why-foreign-countries-are-banning-american-adoptions.html.

6. Civil Code of the Republic of Lithuania (Official Gazette, 2000, No. $\square \square \square \square-1864$ ).

7. Commentary of the Ombudsman of the Republic of Lithuania on the Report of the Republic of Lithuania on the Implementation of the United Nations Convention on the Rights of the Child in Lithuania, 2004-2008, p. 6.

8. Convention on the Protection of Children and Cooperation in Respect of International Adoption, 1993.

9. Constitution of the Republic of Lithuania (Official Gazette, 1992, No 33-1014), Art. 1 p.m., 2 p.

10. Criminal Code of the Republic of Lithuania (Official Gazette, 2000, No. $\square \square \square \square-1968$ ), Art. 1 p.

11. European Convention on Human Rights and Fundamental Freedoms (Official Gazette, 1995, No 40-987).

12. Gončiarova, N. Tamutienè, I. 2016. Interference with Adoption in the Republic of Lithuania. Expert Approach. Public Policy and Administration, 15(2), 251-263.

13. The Hague Convention on Protection of Children and Co-operation in Respect of Intercountry Adoption, Hague Adoption Convention, 1993, entry into force: 1-V-1995. Accessed on 24 January 2020. Available online: https:// www.hcch.net/en/instruments/conventions/full-text/?cid=69.

14. International Covenant on Civil and Political Rights (Official Gazette, 2002, No. 77-3288), Art. 1 p.

15. Law on Fundamentals of Protection of the Rights of the Child, Art. 1 p. Žiūrèta 2020-02-20, Prieiga internetu: https://e-seimas.lrs.lt/portal/legalAct/lt/TAD/TAIS.382481?jfwid=q8i88lquy.

16. Lima, Fernandes Pires de, e Varela, Antunes, Código civil anotado. Coimbra : Coimbra Editora, 5. 1995.

17. Piesliakas, V., 2009, Lithuanian Criminal Law, 1, Vilnius: Justitia.

18. Proceedings of the Senate of the Supreme Court of Lithuania in 2004 June 18 resolution no. 46 on "Review of caselaw in cases concerning crimes against human life". 
19. Sagatys, G. (2006). Children's Right to Family Relations. Vilnius: Legal Information Center.

20. Tarvydienè, O. Accessed on 12 March 2020. Foreigners Will Not Give Healthy Children anymore. Available online: https://www.news.co.uk/news/second/uzsienieciams-nebeduos-health-birth/.html.

21. United Nations Declaration on the Rights of the Child, (Published by the General Assembly, 1959, 1/86 ( $\square \square \square$ ).

\title{
Legal regulation of international adoption in Lithuania and Portugal
}

\author{
Perkumienė Dalia, ${ }^{1}$ Beriozovas Olegas, ${ }^{2}$ Escudeiro Maria João ${ }^{3}$ \\ ${ }^{1}$ Vytautas Magnus University Agriculture Academy, Kaunas, Lithuania \\ ${ }^{2}$ Kazimieras Simonavičius University, Vilnius, Lithuania \\ ${ }^{3}$ Polytechnic Institute of Lisbon and of ISCPSI, and PhD in Criminal Legal Sciences, Portuguese Catholic University, \\ Lisbon, Portugal
}

\begin{abstract}
Research problem and degree of the research. Protecting the rights of the child is one of the most important issues today, both nationally and internationally. The situation is particularly complicated when it comes to international adoption. The adoption institute transcends all cultures and has long since existed, having played different functions over time. This institute has come to reflect social changes relating to how society faces a child's needs, the way of exercising parental responsibilities and the needs of birth parents and adoptive parents. This is a subject increasingly relevant within the phenomenon of globalization and the urgency given to children and their rights in contemporary society. This is a subject for today and for the future.

The adoptive child, due to his or her subjective characteristics, is unable to exercise his or her rights properly. This obligation must be exercised by the child's parents or the State and its authorities. Although the Constitution of the Republic of Lithuania guarantees that every child has the right to grow up in a family, many children do not have a family and are forced to grow up in foster care. In this situation, an adoption institute emerges, which, at least from dallies, gives the child a chance to live in a family. In Portugal, the strong connection between the principle of the child's best interest, major principle of family law, deeply influences the entire legal institute and, specially, the matter of international adoption. The placing of children in a foreign family is a subsidiary option, in great deal due to the difficulties that they will find from the moment they exit their country of origin. Difficulties such as differences in culture, language, religion, habits, among others that may result in children's cultural uprooting and affect their cultural identity, beyond the cut with their biological family, implied in any adoption.
\end{abstract}

Subject of the article: protection of the rights of the child and problems in cross-border adoption.

Aim of the work: to analyze whether the rights of the child in the case of international adoption are violated.

Research methods: teleological, historical, comparative analysis of legislation, generalization, analysis, and synthesis of scientific literature, descriptive, comparative, analytical methods.

The right of the child to grow up in a family is enshrined in the basic international instruments. It is in the family that the life and socialization of each child begins. It creates an atmosphere for the child to grow, develop and explore the world. The child should grow as much as possible to feel the love, care, and responsibility of his parents.

Adoption is a significant process in many states. The main international instrument governing adoption is the Hague Convention on Protection of Children and Cooperation in respect of Intercountry Adoption. States, in accordance with both their national and international legislation on adoption, seek to enable the child to grow up in a new family, while ensuring that such adoption best protects the rights and interests of the child.

In Portugal, the child's best interest is a fundamental concept in this matter, for a true concept of individual rights is one in which the child is considered a subject of rights, and not object of them. This principle is the guiding principle for the exercise of private responsibilities in relation to children, as well as public ones, and should be considered both in state and 
judicial decisions and actions. The child's best interest is an indeterminate legal concept, varying with the customs of each society, taking into evolutionary and dynamic nature, and depending on case-by-case evaluation.

This continues to be a divisive issue in Portugal and Law No. 2/2016, of 29 February eliminates discrimination against persons of the same sex who live in a de facto union or are married, in access to adoption, civil sponsorship and other family legal relationships, making all the legal changes.

Key words: child, adoption, child's right to grow up in a family, international adoption.

Gautas 20200324

Priimtas 20201110 